Discussion

\title{
Unpacking the Lore on Multilingual Scholars Publishing in English: A Discussion Paper
}

\author{
Mary Jane Curry ${ }^{1, *}$ and Theresa Lillis ${ }^{2}$ \\ 1 Warner Graduate School of Education and Human Development, University of Rochester, Rochester, \\ NY 14627, USA \\ 2 Centre for Language and Communication, Faculty of Education and Language Studies, The Open \\ University, Milton Keynes MK7 6 AA, UK; theresa.lillis@open.ac.uk \\ * Correspondence: mjcurry@Warner.Rochester.edu
}

Received: 7 February 2019; Accepted: 2 April 2019; Published: 10 April 2019

\begin{abstract}
In the past three decades, a body of research on issues related to multilingual scholars writing for publication has emerged, paralleling the rise of pressures on scholars around the world to publish their work in high-status journals, especially those included in particular journal citation indexes; these indexes typically privilege the use of English. Researchers have investigated multilingual scholars' experiences and perspectives, the social contexts of their work, policies on research publishing, aspects of the texts produced by multilingual scholars, the kinds of people scholars interact with while working to publish their research, their collaborations and networks, and pedagogical initiatives to support their publishing efforts. Nevertheless, as ongoing research is conducted, the existing research base has not always been consulted in meaningful ways. In this paper, we draw on the notion of 'lore' to identify some of the preconceptions or received wisdom about multilingual scholars and their writing that seem to be circulating, then argue for researchers to move beyond the 'lore' and make greater use of both findings from empirical research and related theoretical and methodological conversations. We identify directions for future research to be conducted.
\end{abstract}

Keywords: research publishing; multilingual writers; academic writing

\section{Introduction: Framing the Concern}

In the past 30 years, academics around the world have increasingly become subject to "evaluation regimes" [1] that quantify research output in multiple ways, often calibrated to high-status journal citation indexes such as those in the Web of Science (Clarivate Analytics) ${ }^{1}$ and driven, for example, by the global rush for university rankings [2]. As a result, pressures on multilingual ${ }^{2}$ scholars to publish in English-medium journals have both intensified (e.g., [3,4] and spread, most recently to Latin America and Africa $[5,6])$. Closely paralleling the development of these pressures to publish, a growing number of researchers have sought to explore and analyze a range of topics related to how established scholars and, more recently, (post)graduate students engage with these pressures (see, e.g., recent books edited by Cargill and Burgess [3], Curry and Lillis [7]; Corcoran, Englander, and Muresan [8]; and Habibie and Hyland [9]); for overviews and discussions of earlier research, see Ammon [10] and Lillis and Curry [11]. Studies have investigated multilingual writers' experiences with, and perceptions of, English-medium publishing within disciplines including applied linguistics [12,13]; humanities [14,15];

\footnotetext{
Known formerly as the Web of Knowledge (Thompson Reuters); even earlier, it was the Institute for Scientific Information. We use this term to refer to scholars who work in contexts where the local language/language of daily communication is not English, recognizing that multilingualism characterizes most regions of the world.
} 
education and psychology [4,16-19]; business [20]; medicine [21,22]; engineering [23,24]; computer science $[25,26]$; and many other science disciplines [27,28]. Widening the lens beyond examining individual scholars' responses, researchers have also critiqued policies that enforce and sustain the pressures for English-medium publishing as well as exploring multilingual scholars' perspectives on these policies (e.g., [4,26,29]). They have also mounted critiques of the influence of the metrics that sustain evaluation regimes for academic knowledge production (e.g., [30,31]). A large segment of work has deconstructed the textual components of published research articles and other genres [32-35]. Another strand of research focuses on journal publishing and gatekeeping practices, in particular, the growth and practices of English-medium journals published outside of Anglophone contexts [1,36-39]; open access journals [40,41]; and "predatory" journals [42,43]; as well as journal publishers and gatekeepers' ideologies and practices [18,44-46]. In recent years, the focus has expanded beyond the preoccupation with the production of research articles to examine other academic genres such as research blogs [35] and wikis [47]. The emergence of formal pedagogies to support multilingual writers to publish in English has also been documented in research mainly reporting on the evaluation of specific initiatives [48-52].

Many of these research topics fall within the tripartite model proposed by Cargill and Burgess [3], which categorizes research as tending to focus on: (a) multilingual authors; (b) journal practices and conventions; and (c) developing publishable texts, all contextualized against "national and institutional policies" (p. 3). Many of these studies have at their centre English-medium publications and have been produced by scholars working in the interrelated disciplines of applied linguistics, English for Academic Purposes (EAP), second language writing, and education, typically drawing on traditions of empirical research. The topic of English-medium publishing has also attracted the attention of scholars working in other empirically oriented disciplines, such as geography [53,54], international relations [55], management [56], and sociology [5]. The research base spans global geolinguistic locations, with work coming from the Anglophone "center"; bi/multilingual contexts such as French-speaking Canada [57]; and locations including Argentina [58]; China [59]; Egypt [60]; Iceland [61]; Japan [23,62]; Kazakhstan [63]; Korea [64]; Mexico [29]; Poland [65]; Romania [66]; Serbia [67]; South Africa [68,69]; Spain [70,71]; Taiwan [50]; and Vietnam [51].

Despite this steady growth of empirically based research studies, however, while attending conferences, serving as peer reviewers for journals, book chapters, and book proposals, and reading recent publications, we have become increasingly aware of persistent mentions to a body of 'lore', or received wisdom, that do not always align with the findings of empirical research or engage with the theoretical discussions advanced in much scholarship on multilingual scholars writing for publication. We argue in this paper that the practice of relying on such lore without considering it against research findings and/or engaging with theoretical and ideological discussions (and taking account of any contradictions arising) may serve to constrain how researchers: (1) understand the complex phenomena entailed in contemporary academic publishing practices; (2) develop research methodologies to investigate the many related issues; (3) unpack the politics of global knowledge production; (4) mount challenges to the presumed global hegemony of English in academic publishing; and (5) design and provide support to multilingual writers. We begin by briefly problematizing a label that has been growing in usage- 'ERPP', or English for research and publication purposes-and continue by discussing the notion of lore in more depth. In the main part of the article, we identify what we see as key topics in the lore circulating among researchers, using Cargill and Burgess's three broad categories as the overall structure.

\section{What Is in a Name? 'ERPP'}

Without denying that many multilingual scholars around the world seek assistance in their English-medium publishing efforts (given the strong pressures to publish in English) or disparaging any motivations of those (including ourselves) who research about, teach, or support them, we also believe that there are dangers in constructing a field of knowledge premised on pedagogical/training 
interests or-in the case of writing for publication-mainly on the effects of the evaluation regimes under which scholars work. There is a risk that such interests and regimes restrict the lenses we use to explore and understand a particular phenomenon [72] and tie us rather into common-sense assumptions or 'lore' (as discussed below). There is a long tradition of reification in fields linked to English indexed by the labels used-for example, English for Academic Purposes (EAP), English for Specific Purposes (ESP)—where the singularity of the term 'English' serves commercial purposes (in terms of global teaching enterprises and the development and dissemination of English-language curriculum materials) and simplifies debates around language practices in formal educational contexts. This reification can also obfuscate our understandings about what exactly it is we are talking about. Such reification has been problematized from disciplinary traditions and perspectives including Critical EAP (e.g., [73-76]), academic literacies [77], and sociology/anthropology [42].

The field of researching the nature, meanings, and consequences of writing for publication in the context of the global dominance of English has managed to avoid for some years being reduced to a specific label denoting specific interventionist interests. We, like others, have been careful to avoid a straightforward label, focusing instead on foregrounding the actual practices in which scholars as well as journal editors and other gatekeepers engage. This commitment has also included consciously using the term 'multilingual/ism' in our labeling both of scholars' language practices and publishing commitments and interests, even where the specific empirical focus has been on publishing in English [16,17]. Researchers have chosen to use phrases such as geopolitics [75], periphery [29], semiperiphery [78], in a global context [4], hegemony [79] and linguistic inequality [80] to avoid framing the phenomenon being explored as being solely textual/linguistic or as involving English construed as a neutral, monolithic, and stable resource, as is implied in 'EAP' and the more recently coined 'ERPP'. Whilst what goes on under the label of EAP and ERPP includes a variety of practices, we do think that names and labels are important. We argue that if our interest is to explore and understand what is involved in writing for publication in contemporary academia, we would be better served intellectually by avoiding easy labeling and reification. In this way, for example, we may avoid having to insert 'critical' before 'ERPP' to claim an intellectual space in the future.

A priority in any academic field is to work hard to rigorously ground our studies and research in existing and ongoing research findings and discussions. In the context of studies of writing for publication, such grounding will enable us to move toward a more nuanced understanding of the situations of scholars around the world. In the next section, we discuss the notion of lore in more depth, then identify what we see as key topics in the lore circulating among researchers, practitioners, and others outside the field, following Cargill and Burgess's framing of (a) multilingual authors; (b) journal practices and conventions; and (c) developing publishable texts.

\section{Why Talk about 'Lore'?}

The notion of lore can be defined as the received wisdom about a particular topic. Another way to consider lore is as "folk theories," which Windschitl [81] defines as "presupposed, taken-for-granted theories about the world that are widely shared by most members of a society" (p. 482). His term 'presupposed' is particularly salient to research on academic writing for publication, because many presuppositions about multilingual scholars' publishing experiences continue to drive research and pedagogy in this field. Most of the existing research literature that contemplates how lore functions in academic writing and knowledge production comes from the U.S. field of rhetoric and composition, a field of scholarship like writing for publication that emerges from the practice of teaching language and literacy. These scholars variously define lore as "underlying assumptions" [82] (p. 188); "common wisdom, often offered as anecdote" [83] (p. 18), and note that it "may operate ... under conditions of lacking or contradictory evidence" [84] (p. 13). Considering scholarship on teaching writing, North [85] elaborates on lore as comprising "bodies of knowledge [that] are not 'scientifically' rigorous ... [but rather] driven by a pragmatic logic ... concerned with what has worked, is working, or might work in teaching, doing, or learning writing" (p. 23). While these questions have also preoccupied 
many people who teach multilingual writers or support them in other ways (e.g., as consultants in writing centers or as authors' editors), for researchers to develop a robust body of academic knowledge requires moving beyond the lore to build on the findings of empirical research ${ }^{3}$. In this vein, while discussing how to write literature reviews in educational research, Kennedy [86] formulates three layers of knowledge construction:

First, there are the primary studies that researchers conduct and publish. Next, there are reviews of those studies, whether systematic or conceptual, that provide summaries and new interpretations built from but often extending beyond the original literature. Finally, there are the perceptions, conclusions, and interpretations that people share in informal hallway conversations that become part of the lore of the field. This third layer is the one most scholars actually believe to be true, but it can have a relatively loose relationship to the primary studies and even to the literature reviews.

(p. 141, emphasis added)

It is these beliefs that become lore as they are decoupled from research and passed on. Drawing on Kennedy's framing, academic lore seems to evolve as scholars become distanced from the primary or empirical research; scholars in rhetoric and composition suggest that practice-based lore acts as a foundation on which to build more rigorous research. In both cases, lore rather than research seems to be what captures scholars' imaginations, as Kennedy explains:

because most of us are too busy to carefully examine entire bodies of literature, we accept secondhand summaries, both in print and in the hallway, a practice that allows each field to generate a particular lore that may or may not match the full scope of primary literature that presumably underlies it. In the lore, some studies get magnified over time and others recede from view.

(p. 141)

In our distinction between research and lore, we use 'research' both to mean empirically based research and to include interpretations and theorizations informed by such research. Together, they constitute the intellectual base from which we as a community of researchers can continue to explore a phenomenon-in this case, writing for publication by multilingual scholars. (See discussions of Haswell's ([87], p. 198) proposal that the field of rhetoric and composition needs to produce more research that is "replicable, aggregable, and data-supported" in Denton [82] and Driscoll and Perdue [83].)

Our aim here is not to deny the relevance of lore when it accurately portrays phenomena related to multilingual scholars' writing, but rather to draw attention to intellectually constraining effects that can occur when certain beliefs (lore) persist despite the existence of research-based findings and critical interpretation and theorization of the significance of these findings. For example, perhaps because many researchers are also teachers of language and/or writing, much of the lore about multilingual writers seems to emerge from a perspective that they need particular kinds of text-based 'remediation' in order to write for publication in English. This perspective denies that multilingual scholars are competent actors entering new academic communities and/or sustaining participation in multiple communities [4]. Whilst some multilingual scholars, like monolingual scholars, may desire certain kinds of support to produce academic texts, the kind of support that might be most useful might not be text-based practice or solutions, but rather, for example, involvement in meaningful academic research networks $[4,88,89]$.

3 By "empirical research," we mean investigations that systematically analyze data or evidence to build and support claims, though not limited to quantitative research, as a common misconception suggests. However, empirical research does not need to be 'replicable' in the positivist sense. 
The reliance on the lore as the starting point for research investigations or as inflecting interpretations can thus be detrimental. While lore can drive the research in a field forward by suggesting questions to be investigated, it can also stymie the development of a field by recycling received wisdom - through framing investigations in particular ways (e.g., "the challenges facing multilingual writers") or sidestepping the accumulated findings of the existing body of research.

In the following section, we list eight positions that we have found to be increasingly circulating - in conference presentations and publications submitted for review-and that we think cannot be sustained by actual research and theorizations. In challenging these positions, we draw on findings from our longitudinal research about 50 psychology and education scholars in central and southern Europe $[4,16,17,90,91]$ alongside the considerable volume of work conducted by other researchers in the field to challenge what we see as the lore, or common presuppositions. We then signal where we believe additional research could usefully be undertaken as the field develops.

\section{Lore about Multilingual Writers}

\subsection{Multilingual Scholars Are Novices Who Automatically Face Challenges and Problems in Writing for Publication in English}

Research findings: Like all scholars, multilingual scholars have varying amounts of expertise with writing for publication, regardless of the language used. Many established multilingual scholars have published research in their local language(s) as well as in other languages (see [4], Ch. 1). These "senior" scholars, in the junior/senior binary that Swales [92] asserts, build on existing expertise by adding new experiences with and knowledge about the publishing practices of English-medium journals [16,93]. While some scholars may feel that writing for publication remains difficult throughout their careers (see, e.g., the discussion in Casanave [94]), for others, writing gets easier over time. In addition, individual authors may find specific genres or subgenres more or less difficult to write, for example, methods as compared with discussion sections of research articles [4].

In contrast to established scholars, early career scholars and students are more likely to be novices to all aspects of the social and linguistic practices of academic publishing [50,95-99]. To avoid collapsing multilingual writers into the "novice" or "junior" category, researchers need to make finer-grained distinctions that take into account the totality of multilingual scholars' knowledge and experience with academic publishing. Framing research about multilingual scholars' practices primarily in terms of a novice-to-expert trajectory devalues the expertise of experienced academics and may preclude researchers from acknowledging and further exploring scholars' linguistic and rhetorical assets and resources.

Future research directions: To date, while English-medium writing has attracted the dominant research focus, the text history analytic approach we have developed shows how many multilingual scholars may draw on their local languages in the process of writing for publication in English [4]; similarly, Salö [25] maps out how Swedish scholars use both Swedish and English in the research process. More research is needed on how scholars use multiple languages in academic communications and the effects of these practices and choices on their work lives and on global knowledge production. Studies could investigate language choices at particular moments in scholars' work lives, how their publications in other languages are evaluated and rewarded, and the consequences of these choices for global knowledge production and circulation (i.e., through citations and the languages used in specific journals $[53,100]$ ). In terms of novice writers for publication (graduate students and early career scholars), additional research is needed on how less experienced scholars, from any linguistic background(s), working in any context, learn the social and linguistic practices entailed in publishing in multiple genres and different types of outlets (e.g., [9]). Researchers also need to continue to explore the complexity of writing practices related to scholars' goals, interests, disciplines, and sociopolitical contexts. 
4.2. Multilingual Scholars Only Want to Publish in Prestigious English-Medium Journals and Have Stopped Publishing in Their Local Language(s)

Research findings: Despite growing pressure from many institutions and governments to publish their work in highly ranked English-medium journals, many multilingual scholars continue to enact their personal commitments to contributing to other communities in other languages $[16,65,101]$. In addition to directing work at national and transnational research communities as well as local practice communities, some scholars are engaging in what we call "equivalent" publishing [4], that is, repurposing texts in different languages for multiple audiences, but doing so in more complex ways than directly translating a text.

Future research directions: As pressures to publish in English spread to less-resourced regions of the globe, it is important to understand scholars' uses of local languages in texts for publications, the communities to which they address specific texts, and for which purposes. Ammon [10] identifies the need "to know the real proportions of language use and to what extent data on language shares in scientific publication are actually skewed" (p. 126). In parallel, monitoring shifting patterns in how institutions evaluate scholars' publications in local languages and reward or disincentivize scholars to pursue multilingual publishing agendas (e.g., $[39,63]$ ) will be important for understanding ongoing developments in global knowledge production.

\subsection{Multilingual Scholars Are Unquestioningly Accepting the Pressure to Publish in English-Medium Journals}

Research findings: While many scholars see publishing in English-medium journals as aligning with their personal objectives and strategies [90], scholars such as Canagarajah [102] are also resisting the codification and evaluation of this activity. One reason has to do with disciplinary traditions of language of publication, with humanities scholars sometimes feeling it absurd to publish in English on topics related to local language, linguistics, literature, and history [103]. Another reason is that English-medium publishing may be displacing research that is important to the local context in terms of intellectual and social development $[4,78]$. In response, scholars adopt "strategies and tactics" through which they publish in English at certain moments, whereas at other times they use local languages for their writings [90]. Scholars are also actively challenging policies that reward prioritizing English-medium publications. In Taiwan, for example, academics signed a petition protesting the government's publishing policies $[104,105]$. And in some cases, later-career scholars become empowered to disregard policies or implicit pressures for English-medium publishing in favor of their own agendas [91].

Future research directions: Documenting and analyzing the impact of the ideology in academia that English is the only important language of academic communication globally continues to be necessary to provide a complete picture of multilingual scholars' contributions to global knowledge production. Tracing the effects of such ideology can follow multiple pathways.

\subsection{Multilingual Scholars Are Not Disadvantaged When Trying to Get Their Work Published in English}

Research findings: While all scholars, especially novices, need to learn the social practices of academic publishing, research shows that many multilingual scholars feel they face a "dual burden" in writing in English that considerably increases their workloads and generates anxiety and dissatisfaction $[106,107]$. Maintaining publishing agendas in multiple languages clearly takes up more time and is an aspect of academic labor that is often core to the professional lives of scholars working in non-English dominant contexts, whilst often ignored or hardly experienced by most monolingual scholars [16]. In terms of responses to texts, journal gatekeepers may exhibit an ideology that standard English(es) should be used [108]. Multilingual scholars' texts may also elicit biases in the responses of journal editors and reviewers, biases against the writers themselves as users of English as an additional language and against research coming from non-Anglophone center locations $[4,18]$.

Future research directions: Understanding which additional requirements or burdens are placed on multilingual scholars when they publish in English-medium journals is crucial not only to add 
information to the debate about whether multilingual scholars are disadvantaged, but also to identify the resources needed to support them in meeting their goals. Additional research could explore the role of various material resources in supporting scholars' publishing [109], the extent to which writing support personnel or programs can help scholars who wish to publish in English, and differences or similarities in the experiences of novice and experienced writers with getting published.

\section{Lore about Journal Practices and Conventions}

\subsection{Producing Error-Free, Native-Like, 'Standard' Written English Is the Main Way to Secure Publication in English-Medium Journals}

Research findings: While being highly proficient in English is clearly useful for multilingual writers, it is neither the sole prerequisite for, nor a guarantee of, publishing success [89]. In fact, getting published also requires gaining access to resources, both discursive and "non-discursive" [109]; see also [51,110]; learning the varying social practices of journals; interacting with different kinds of "literacy brokers" [17,111]; and participating in academic research networks [88,89]. Further, English-medium academic journal publishing has been diversifying in a number of ways: (1) multilingual scholars are submitting more of their papers to transnational English-medium journals and more of their work is being published [112]; (2) more English-medium journals are being produced outside of the Anglophone center [1,38]; (3) and some journals are allowing greater linguistic variety in the English used [45,113]. At the same time, dominant ideologies about the use of "standard" English being required continue to hold sway among many journal gatekeepers-reviewers and editors [18,46].

Future research directions: As publishing is often considered to be the culminating goal of research activity, more investigations need to start from the perspective that writing for publication is one part of a broader set of research practices. In this view, writing is integrated into many aspects and moments of research activity rather than only coming at the end of the process [114]. In addition, more research is needed that unpacks the dynamic nature of the linguistic practices of English-medium journals, including how writers use English in evolving ways and how readers and evaluators take up their texts. Of course methodological challenges can arise in terms of obtaining and analyzing data on how gatekeepers, readers, and evaluators take up these publications.

\subsection{All English-Medium Journals Require the Use of Common Rhetorical Structures in the Articles They Publish}

Research findings: While it is important for writers to identify specific target journals for particular texts they are developing and to follow journals' guidelines for authors, acceptance of article submissions also depends on whether a manuscript engages with a journal's "conversations" by responding to the current research literature in terms of how it handles research questions, methodologies, theories, as well as rhetorical structure and language use $[115,116]$. Indeed, our research shows a strong centripetal pull toward the interplay of research topics, preferred research methodologies, and currently circulating theoretical lenses [18]. However, even within rigid regimes of practice and evaluation, variety has been documented, such as, for example, the order of sections in research articles [117-119]. Swales [120] in fact advocates for "experimentation in both style and substance" of academic writing, suggesting that established conventions can be successfully flouted and not only by senior scholars (p. 251).

Future research directions: Given the steady proliferation of academic journals (a rate of almost five percent per year) [121], and the growth in English-medium journals published outside the Anglophone center, more research is needed on the patterns and preferences of journals across academic (sub)disciplines as well as geolinguistic locations, in particular to study how dominant center-based ideologies of language and rhetoric affect multilingual scholars' practices of text production and how their texts are taken up. 


\section{Lore about Developing Publishable Texts}

\subsection{Having A "Native English Speaker" Review a Text Will Help It Get Accepted by a Journal}

Research findings: A range of people called authors' editors, copyeditors, translators, or other "language brokers" [17] may help authors with the language, structure, and other aspects of their texts. However, because publishing requires more than using "standard" forms of English, as discussed above, receiving support only at the level of language does not guarantee success. Indeed, different types of brokers can offer distinct types and levels of support. In our study, "academic literacy brokers," that is, academic colleagues who work in an author's (sub)discipline, can share knowledge of publishing opportunities and practices, identify particular journals and their interests, provide linguistic/rhetorical feedback on texts in development, and coach authors on responding to editors and peer reviewers [17]. In contrast, language brokers who are unfamiliar with an author's (sub)discipline may not have the necessary knowledge of disciplinary practices, including linguistic and rhetorical preferences, to support success in publication.

Future research directions: While interest has been growing in how a range of people intervene in the development of an author's texts, more research needs to illuminate the collaborative nature of academic writing for publication, whether such collaboration is named or unnamed, pre- or post-submission (e.g., [26,122]). In the case of novice scholars, while studies have explored the involvement of laboratory co-workers and advisors in their publishing efforts [99,123], more research on this topic would be beneficial (for a literature review, see Li [124]).

\subsection{Taking Text-Based Courses or Workshops Will Necessarily Help Scholars Get Their Work Published}

Research findings: Research on the rise of pedagogies to support publishing has documented that initiatives focusing only on the linguistic and rhetorical aspects of texts written for publication and neglecting the social practices and politics of English-medium publishing may not help authors explore the key publishing practices of target journals [49]. Workshops may also be insufficient if scholars lack subsequent access to literacy brokers who can support them during the trajectory of writing and submitting articles. Some research suggests that academic courses on writing for publication also benefit from being collaboratively designed and taught by writing and disciplinary specialists [48, 50]. However, much of the research in this field to date has described the authors' own initiatives, often drawing on participants' self-reports of satisfaction (through, e.g., post-workshop surveys), but without longitudinal monitoring of how participants subsequently fare in their publishing efforts.

Future research directions: Pedagogical research using ethnographic and other qualitative methods, in addition to the commonly used surveys of participant satisfaction, would provide more robust understandings of how pedagogies may or may not support participants' goals. Establishing whether particular approaches are effective in terms of participants' manuscripts being accepted for publication long after being involved in specific pedagogies, however, would require tracking participants' publications records through longitudinal research designs spanning a number of years. Additional studies on how scholars receive advice and support to respond to gatekeepers' communications, for example, could generate useful information.

\section{Conclusions and Implications}

In this paper, we have argued that an overreliance on the lore by researchers seeking to investigate academic writing for publication can have detrimental effects on the production of knowledge in this area by distorting the object of inquiry (multilingual scholars and students writing for publication) and thus the design of investigations and the interpretation of data. We have contrasted what we see as the lore in the three broad areas-multilingual scholars, journal practices and conventions, and developing publishable texts-with the related research findings, and suggested directions for future research. We identify a relationship among the assumptions underpinning the lore that are often driven by the aims of institutional and geolinguistic regimes of evaluation: the assumption that multilingual writers 
need mainly to improve their English; preconceptions about what journals are looking for; and the design of publishing pedagogies that focus on textual features rather than social practices and politics. In fact, relying on lore tends to preclude researchers undertaking open-ended and exploratory avenues of research that are not tied to the assumptions driven by regimes of evaluation [7]. Our aim has been to open a discussion about this lore and encourage others to consider whether these points have relevance for their research and possibly their teaching practice.

Research presentations and publications that derive their impetus from the lore can leave the audience with the impression that the major research questions about multilingual scholars' and publishing practices have been answered (e.g., the mounting pressures on multilingual scholars, the policies these pressures may emerge from, how scholars respond to pressures, the resources available to scholars, their experiences while writing and submitting papers to journals, journals' feedback, etc.). However, we are not alone in identifying additional research directions: In addition to our suggestions articulated above, Ammon ([10] pp. 126-130) points to additional research questions that still need to be addressed, for example: the reading practices of research published in languages other than English (by whom and for what purposes); the value of obtaining accurate information on the presumed flow of academic information outward from the Anglophone 'center' and reasons for this flow; the benefits and drawbacks of a presumed lingua franca for knowledge production (English); possible means of compensation for scholars laboring under the additional burden of publishing in English; and changes in the acceptance of 'non-standard' varieties of English as increasing numbers of people around the world use English professionally.

Author Contributions: Both authors contributed equally to this article, which draws on 18 years of collaboration and discussion of this research field and our joint research.

Funding: The bibliographic research reported on in this paper has received no funding.

Conflicts of Interest: The authors declare no conflict of interest.

\section{References}

1. Lillis, T. Economies of signs in writing for academic publication: The case of English medium "national" journals. JAC 2012, 32, 695-722.

2. Post, D. The future of education research publishing: Challenges and responses. Educ. Policy Anal. Arch. 2014, 22. [CrossRef]

3. Publishing Research in English as an Additional Language: Practices, Pathways and Potentials; Cargill, M.; Burgess, S. (Eds.) University of Adelaide Press: Adelaide, Australia, 2017.

4. Lillis, T.; Curry, M.J. Academic Writing in a Global Context: The Politics and Practices of Publishing in English; Routledge: London, UK, 2010.

5. Beigel, F. Publishing from the periphery: Structural heterogeneity and segmented circuits. The evaluation of scientific publications for tenure in Argentina's CONICET. Curr. Sociol. 2014, 62, 743-765. [CrossRef]

6. Mweru, M. Why Kenyan Academics do not Publish in International Refereed Journals; World Social Science Report: Knowledge Divides; UNESCO: Paris, France, 2010.

7. Curry, M.J.; Lillis, T. Problematizing english as the privileged language of global academic publishing. In Global Academic Publishing: Policies, Perspectives and Pedagogies; Curry, M.J., Lillis, T., Eds.; Multilingual Matters: Bristol, UK, 2018; pp. 1-20.

8. Pedagogies and Policies for Publishing Research in English: Local Initiatives Supporting International Scholars; Corcoran, J.N.; Englander, K.; Muresan, L.M. (Eds.) Routledge: New York, NY, USA, 2019.

9. Novice Writers and Scholarly Publication: Authors, Mentors, Gatekeepers; Habibie, P.; Hyland, K. (Eds.) Palgrave Macmillan: Cham, Switzerland, 2019.

10. Ammon, U. Global scientific communication: Open questions and policy suggestions. AILA Rev. 2007, 20, 123-133. [CrossRef]

11. Lillis, T.; Curry, M.J. Academic writing for publication in a multilingual world. In Handbook of Second and Foreign Language Writing; Manchon, R., Matsuda, P.K., Eds.; Mouton de Gruyter: Berlin, Germany, 2016; pp. 201-222. 
12. Belcher, D.D. Seeking acceptance in an English-only research world. J. Second Lang. Writ. 2007, 16, 1-22. [CrossRef]

13. Liu, J. Co-constructing academic discourse from the periphery: Chinese applied linguists' centripetal participation in scholarly publication. Asian J. Engl. Lang. Teach. 2004, 14, 1-22.

14. Buckingham, L. Development of english academic writing competence by Turkish scholars. Int. J. Dr. Stud. 2008, 3, 1-18. [CrossRef]

15. Ge, M. English writing for international publication in the age of globalization: Practices and perceptions of mainland Chinese academics in the humanities and social sciences. Publications 2015, 3, 43-64. [CrossRef]

16. Curry, M.J.; Lillis, T. Multilingual scholars and the imperative to publish in English: Negotiating Interests, demands, and rewards. TESOL Q. 2004, 38, 663-688. [CrossRef]

17. Lillis, T.; Curry, M.J. Professional academic writing by multilingual scholars: Interactions with literacy brokers in the production of English-medium texts. Writ. Commun. 2006, 3, 3-35. [CrossRef]

18. Lillis, T.; Curry, M.J. The politics of English, language and uptake: The case of international academic journal article reviews. AILA Rev. 2015, 28, 127-150.

19. Mertkan, S.; Arsan, N.; Inal Cavlan, G.; Onurkan Aliusta, G. Diversity and equality in academic publishing: The case of educational leadership. Compare 2017, 47, 46-61. [CrossRef]

20. Li, Y.; Cheng, R. Chinese business schools pursuing growth through international publication: Evidence from institutional genres. In Global Academic Publishing: Policies, Perspectives and Pedagogies; Curry, M.J., Lillis, T., Eds.; Multilingual Matters: Bristol, UK, 2018; pp. 50-69.

21. Giannoni, D.S. Medical writing at the periphery: The case of Italian journal editorials. J. Engl. Acad. Purp. 2008, 7, 97-107. [CrossRef]

22. ElMalik, A.; Nesi, H. Publishing research in a second language: The case of Sudanese contributors to international medical journals. J. Engl. Acad. Purp. 2008, 7, 87-96. [CrossRef]

23. McDowell, L.; Liardét, C.L. Japanese materials scientists' experiences with English for research publication purposes. J. Engl. Acad. Purp. 2019, 37, 141-153. [CrossRef]

24. Shaw, P. Science research students' composing processes. Engl. Specif. Purp. 1991, 10, 189-206. [CrossRef]

25. Salö, L. The linguistic sense of placement: Habitus and the entextualization of translingual practices in Swedish academia. J. Socioling. 2015, 19, 511-534. [CrossRef]

26. Solin, A.; Hynninen, N. Regulating the language of research writing: Disciplinary and institutional mechanisms. Lang. Educ. 2018, 32, 494-510. [CrossRef]

27. Englander, K. Revision of scientific manuscripts by nonnative-English-speaking scientists in response to journal editors' criticism of the language. J. Appl. Linguist. 2006, 3, 129-161.

28. Kheimets, N.G.; Epstein, A.D. English as a central component of success in the professional and social integration of scientists from the former Soviet Union in Israel. Lang. Soc. 2001, 30, 187-215. [CrossRef]

29. Englander, K.; Uzuner-Smith, S. The role of policy in constructing the peripheral scientist in the era of globalization. Lang. Policy 2013, 12, 231-250. [CrossRef]

30. Nygaard, L.P.; Bahgat, K. What's in a number? How (and why) measuring research productivity in different ways changes the gender gap. J. Engl. Acad. Purp. 2018, 32, 67-79. [CrossRef]

31. Nygaard, L.P.; Bellanova, R. Lost in quantification: Scholars and the politics of bibliometrics. In Global Academic Publishing: Policies, Perspectives and Pedagogies; Curry, M.J., Lillis, T., Eds.; Multilingual Matters: Bristol, UK, 2018; pp. 23-36.

32. Samraj, B. Introductions in research articles: Variations across disciplines. Engl. Specif. Purp. 2002, 21, 1-17. [CrossRef]

33. Sheldon, E. Dialogic spaces of knowledge construction in research article Conclusion sections written by English L1, English L2 and Spanish L1 writers. Ibérica 2018, 35, 13-40.

34. Swales, J.M. Research Genres: Explorations and Applications; Cambridge University Press: Cambridge, UK, 2004.

35. Luzón, M.-J. Constructing academic identities online: Identity performance in research group blogs written by multilingual scholars. J. Engl. Acad. Purp. 2018, 33, 24-39. [CrossRef]

36. Cárdenas, M.L. Publishing and academic writing: Experiences of authors who have published in PROFILE. Profile Issues Teach. Prof. Dev. 2014, 16, 11-20. [CrossRef]

37. Flowerdew, J. Attitudes of journal editors to nonnative speaker contributions. TESOL Q. 2001, 35, 121-150. [CrossRef] 
38. Sheridan, C.L. National journals and centering institutions: A historiography of an English language teaching journal in Taiwan. Engl. Specif. Purp. 2015, 38, 70-84. [CrossRef]

39. Sheridan, C.L. Blind peer review at an English language teaching journal in Taiwan: Glocalized practices wihtin the globalization of higher education. In Global Academic Publishing: Policies, Perspectives and Pedagogies; Curry, M.J., Lillis, T., Eds.; Multilingual Matters: Bristol, UK, 2018; pp. 136-150.

40. Bocanegra-Valle, A. "English is my default academic language": Voices from LSP scholars publishing in a multilingual journal. J. Engl. Acad. Purp. 2014, 13, 65-77. [CrossRef]

41. Salager-Meyer, F. Open access: The next model for research dissemination. In Global Academic Publishing: Policies, Perspectives and Pedagogies; Curry, M.J., Lillis, T., Eds.; Multilingual Matters: Bristol, UK, 2018; pp. 184-199.

42. Ebadi, S.; Zamani, G. Predatory publishing as a case of symbolic violence: A critical English for academic purposes approach. Cogent Educ. 2018, 5, 1501889. [CrossRef]

43. Fazel, I.; Heng Hartse, J. Reconsidering "predatory" open access journals in an age of globalised English-language academic publishing. In Global Academic Publishing: Policies, Perspectives and Pedagogies; Curry, M.J., Lillis, T., Eds.; Multilingual Matters: Bristol, UK, 2018; pp. 200-213.

44. Anderson-Levitt, K. Significance: U.S. blind spots in judging research. Educ. Policy Anal. Arch. $2014,22$. [CrossRef]

45. Martinez, R. "Specially in the last years ... ": Evidence of ELF and non-native English forms in international journals. J. Engl. Acad. Purp. 2018, 33, 40-52. [CrossRef]

46. McKinley, J.; Rose, H. Conceptualizations of language errors, standards, norms and nativeness in English for research publication purposes: An analysis of journal submission guidelines. J. Second Lang. Writ. 2018, 42, 1-11. [CrossRef]

47. Kuteeva, M. Wikis and academic writing: Changing the writer-reader relationship. Engl. Specif. Purp. 2011, 30, 44-57. [CrossRef]

48. Cargill, M.; O'Connor, P. Developing Chinese scientists' skills for publishing in English: Evaluating collaborating-colleague workshops based on genre analysis. J. Engl. Acad. Purp. 2006, 5, 207-221. [CrossRef]

49. Corcoran, J. The potential and limitations of an English for research publication purposes course for Mexican scholars. In Global Academic Publishing: Policies, Perspectives and Pedagogies; Curry, M.J., Lillis, T., Eds.; Multilingual Matters: Bristol, UK, 2018; pp. 233-248.

50. Huang, J.C. Teaching writing for publication in English to engineering students: Implications from a collaborative course in Taiwan. In Global Academic Publishing: Policies, Perspectives and Pedagogies; Curry, M.J., Lillis, T., Eds.; Multilingual Matters: Bristol, UK, 2018; pp. 217-232.

51. Cao Xuan, T.A.; Cadman, K. Training "clerks of the [global] empire” for 21st-century Asia? English for Research Purposes (ERP) in Vietnam. In Publishing Research in English as an Additional Language: Practices, Pathways and Potentials; Cargill, M., Burgess, S., Eds.; University of Adelaide Press: Adelaide, Australia, 2017; pp. 221-238.

52. Matarese, V. Supporting Research Writing: Roles and Challenges in Multilingual Settings; Chandos Publishing: Oxford, UK, 2013.

53. Bajerski, A.; Przygoński, K. East-Central European human geographers in English-dominated, Anglophone-based international publishing space. Geogr. Pol. 2018, 91, 265-280. [CrossRef]

54. Paasi, A. Academic capitalism and the geopolitics of knowledge. In The Wiley Blackwell Companion to Political Geography; Agnew, J., Mamadouh, V., Secor, A.J., Sharp, J., Eds.; Wiley Blackwell: Hoboken, NJ, USA, 2015; pp. 507-523.

55. Aydinli, E.; Mathews, J. Are the core and periphery irreconcilable? The curious world of publishing in contemporary international relations. Int. Stud. Perspect. 2000, 1, 289-303. [CrossRef]

56. Tietze, S.; Dick, P. Hegemonic practices and knowledge production in the management academy: An English language perspective. Scand. J. Manag. 2009, 25, 119-123. [CrossRef]

57. Gentil, G.; Séror, J. Canada has two official languages-Or does it? Case studies of Canadian scholars' language choices and practices in disseminating knowledge. J. Engl. Acad. Purp. 2014, 13, 17-30. [CrossRef]

58. Zarowsky, M.; Justo von Lurzer, C. Communication research in Argentina (2001-2015): Between expansion and intellectual intervention. Commun. Theory 2018, 28, 202-223. [CrossRef]

59. Zheng, Y.; Guo, X. Publishing in and about English: Challenges and opportunities of Chinese multilingual scholars' language practices in academic publishing. Lang. Policy 2018, 18, 107-130. [CrossRef] 
60. Shehata, A.M.K.; Eldakar, M.A.M. Publishing research in the international context: An analysis of Egyptian social sciences scholars' academic writing behaviour. Electron. Libr. 2018, 36, 910-924. [CrossRef]

61. Ingvarsdóttir, H.; Arnbjörnsdóttir, B. ELF and academic writing: A perspective from the Expanding Circle. J. Engl. Ling. Fr. 2013, 2, 123-145. [CrossRef]

62. Okamura, A. How do British and Japanese scientists publish their academic papers in English? Econ. J. Tak. City Univ. Econ. 2004, 46, 39-61.

63. Kuzhabekova, A. The reaction of scholarly journals to impact-factor publishing requirements in Kazakhstan. In Global Academic Publishing: Policies, Perspectives and Pedagogies; Curry, M.J., Lillis, T., Eds.; Multilingual Matters: Bristol, UK, 2018; pp. 121-135.

64. Lee, H.; Lee, K. Publish (in international indexed journals) or perish: Neoliberal ideology in a Korean university. Lang. Policy 2013, 12, 215-230. [CrossRef]

65. Duszak, A.; Lewkowicz, J. Publishing academic texts in English: A Polish perspective. J. Engl. Acad. Purp. 2008, 7, 108-120. [CrossRef]

66. Muresan, L.M.; Pérez-Llantada, C. English for research publication and dissemination in bi-/multiliterate environments: The case of Romanian academics. J. Engl. Acad. Purp. 2014, 13, 53-64. [CrossRef]

67. Filipovič, J.; Vučo, J. Small area languages in global academic settings. Actual. Comun. Soc. 2013, $136-139$.

68. Abdulatief, S.; Guzula, X. Emerging academics: Using WhatsApp to share novice and expert resources in a postgraduate writing group. In Global Academic Publishing: Policies, Perspectives and Pedagogies; Curry, M.J., Lillis, T., Eds.; Multilingual Matters: Bristol, UK, 2018; pp. 249-263.

69. Van Der Merwe, M. Doctoral writing for publication at a leading African university: Publication patterns and pedagogies. Perspect. Educ. 2015, 33, 92-107.

70. Martín, P.; Rey-Rocha, J.; Burgess, S.; Moreno, A.I. Publishing research in English-language journals: Attitudes, strategies and difficulties of multilingual scholars of medicine. J. Engl. Acad. Purp. 2014, 16, 57-67. [CrossRef]

71. López-Navarro, I.; Moreno, A.I.; Burgess, S.; Sachdev, I.; Rey-Rocha, J. Publicar en inglés o en castellano: Un marco teórico para el estudio de las motivaciones de los investigadores; Why publish in English versus Spanish?: Towards a framework for the study of researchers' motivations. Rev. Española Doc. Cientifica 2015, 21, 22-25.

72. Lillis, T. Resistir regímenes de evaluación en el estudio del escribir: Hacia un imaginario enriquecido. Signo $Y$ Pensam. 2017, 36, 66-81.

73. Benesch, S. Theorizing and practicing critical English for academic purposes. J. Engl. Acad. Purp. 2009, 8, 81-85. [CrossRef]

74. Canagarajah, A.S. Resisting Linguistic Imperialism in English Teaching; Oxford University Press: Oxford, UK, 1999.

75. Canagarajah, A.S. A Geopolitics of Academic Writing; University of Pittsburgh Press: Pittsburgh, PA, USA, 2002.

76. Harwood, N.; Hadley, G. Demystifying institutional practices: Critical pragmatism and the teaching of academic writing. Engl. Specif. Purp. 2004, 23, 355-377.

77. Lillis, T.; Tuck, J. Academic Literacies: A critical lens on writing and reading in the acdemy. In The Routledge Handbook of English for Academic Purposes; Ken, H., Shaw, P., Eds.; Routledge: London, UK, 2016; pp. $30-43$.

78. The Semiperiphery of Academic Writing: Discourse, Communities and Practices; Bennett, K. (Ed.) Palgrave Macmillan: Basingstoke, UK, 2014.

79. Faraldo-Cabana, P. Research excellence and anglophone dominance: The case of law, criminology and social science. In The Palgrave Handbook of Criminology and the Global South; Carrington, K., Hogg, R., Scott, J., Sozzo, M., Eds.; Springer International Publishing: Cham, Switzerland, 2018; pp. 163-181.

80. Carli, A.; Ammon, U. Introduction to the topic. Aila Rev. 2007, 20, 1-3. [CrossRef]

81. Windschitl, M. Folk theories of "inquiry:" How preservice teachers reproduce the discourse and practices of an atheoretical scientific method. J. Res. Sci. Teach. 2004, 41, 481-512. [CrossRef]

82. Denton, K. Beyond the lore: A case for asynchronous online tutoring. Writ. Cent. J. 2017, 36, 175-203.

83. Driscoll, D.; Perdue, S.W. Theory, lore, and more: An analysis of RAD research in The Writing Center Journal. Writ. Cent. J. 2012, 32, 11-39.

84. Graham, S.S. Guest editorial: Data and lore in technical communication research. Commun. Des. Q. 2012, 5, 8-25. [CrossRef]

85. North, S. The Making of Knowledge in Composition: Portrait of an Emerging Field; Boynton/Cook: Portsmouth, NH, USA, 1987.

86. Kennedy, M.M. Defining a literature. Educ. Res. 2007, 36, 139-147. [CrossRef] 
87. Haswell, R.H. NCTE/CCCC's recent war on scholarship. Writ. Commun. 2005, 22, 198-223. [CrossRef]

88. Curry, M.J.; Lillis, T. Academic research networks: Accessing resources for English-medium publishing. Engl. Specif. Purp. 2010, 29, 281-295. [CrossRef]

89. Lillis, T.; Curry, M.J. Reframing notions of competence in scholarly writing: From individual to networked activity. Rev. Canar. Estud. Ingl. 2006, 53, 63-78.

90. Curry, M.J.; Lillis, T.M. Strategies and tactics in academic knowledge production by multilingual scholars. Educ. Policy Anal. Arch. 2014, 22. [CrossRef]

91. Lillis, T.; Curry, M.J. Trajectories of knowledge and desire: Multilingual women scholars researching and writing in academia. J. Engl. Acad. Purp. 2018, 32, 53-66. [CrossRef]

92. Swales, J. Genre Analysis: English in Academic and Research Settings; Cambridge University Press: Cambridge, UK; New York, NY, USA, 1990.

93. McGrath, L. Parallel language use in academic and outreach publication: A case study of policy and practice. J. Engl. Acad. Purp. 2014, 13, 5-16. [CrossRef]

94. Casanave, C.P. Does writing for publication ever get easier? Some reflections from an experienced scholar. In Novice Writers and Scholarly Publication: Authors, Mentors, Gatekeepers; Habibie, P., Hyland, K., Eds.; Palgrave Macmillan: Cham, Switzerland, 2019; pp. 135-151.

95. Anderson, L. Publishing strategies of young, highly mobile academics: The question of language in the European context. Lang. Policy 2013, 12, 273-288. [CrossRef]

96. Anderson, L. Publishing in pursuit of an academic career: The role of embedded and encultured knowledge in national job-market entry strategies of elite early career European scholars. In Global Academic Publishing: Policies, Perspectives and Pedagogies; Curry, M.J., Lillis, T., Eds.; Multilingual Matters: Bristol, UK, 2018; pp. 103-118.

97. Li, Y.; Flowerdew, J.; Cargill, M. Teaching English for Research Publication Purposes to science students in China: A case study of an experienced teacher in the classroom. J. Engl. Acad. Purp. 2018, 35, 116-129. [CrossRef]

98. Nagano, R.; Spiczéné, E. PhD publication requirements and practices: A multidisciplinary case study from a Hungarian university. In Global Academic Publishing: Policies, Perspectives and Pedagogies; Curry, M.J., Lillis, T., Eds.; Multilingual Matters: Bristol, UK, 2018; pp. 37-49.

99. Tardy, C.M. "It's like a story": Rhetorical knowledge development in advanced academic literacy. J. Engl. Acad. Purp. 2005, 4, 325-339. [CrossRef]

100. Lillis, T.; Hewings, A.; Vladimirou, D.; Curry, M.J. The geolinguistics of English as an academic lingua franca: Citation practices across English-medium national and English-medium international journals. Int. J. Appl. Linguist. 2010, 20, 111-135. [CrossRef]

101. Harbord, J. Language policy and the disengagement of the international academic elite. In Global Academic Publishing: Policies, Perspectives and Pedagogies; Curry, M.J., Lillis, T., Eds.; Multilingual Matters: Bristol, UK, 2018; pp. 88-102.

102. Flowerdew, J.; Li, Y. English or Chinese? The trade-off between local and international publication among Chinese academics in the humanities and social sciences. J. Second Lang. Writ. 2009, 18, 1-16. [CrossRef]

103. Arnbjörnsdóttir, B.; Ingvarsdóttir, H. Issues of identity and voice: Writing English for research purposes in the semi-periphery. In Global Academic Publishing: Policies, Perspectives and Pedagogies; Curry, M.J., Lillis, T., Eds.; Multilingual Matters: Bristol, UK, 2018; pp. 73-87.

104. Min, H.T. Participating in International Academic Publishing: A Taiwan Perspective. TESOL Q. 2014, 48, 188-200. [CrossRef]

105. Chou, C.P.; Lin, H.F.; Chiu, Y.J. The impact of SSCI and SCI on Taiwan's academy: An outcry for fair play. Asia Pac. Educ. Rev. 2013, 14, 23-31. [CrossRef]

106. Hanauer, D.I.; Englander, K. Quantifying the burden of writing research articles in a second language: Data from Mexican scientists. Writ. Commun. 2011, 28, 403-416. [CrossRef]

107. Hanauer, D.I.; Sheridan, C.L.; Englander, K. Linguistic injustice in the writing of research articles in English as a second language: Data from Taiwanese and Mexican researchers. Writ. Commun. 2019, 36, 136-154. [CrossRef]

108. Hewings, M. An "important contribution" or "tiresome reading"?: A study of evaluation in peer reviews of journal article submissions. J. Appl. Linguist. 2004, 1, 247-274. [CrossRef] 
109. Canagarajah, A.S. "Nondiscursive" requirements in academic publishing, material resources of periphery scholars, and the politics of knowledge production. Writ. Commun. 1996, 13, 435-472. [CrossRef]

110. Cargill, M.; O'Connor, P.; Raffiudin, R.; Sukarno, N.; Juliandi, B.; Rusmana, I. Scientists publishing research in English from Indonesia: Analyzing outcomes of a training intervention to inform institutional action. In Publishing Research in English as an Additional Language: Practices, Pathways and Potentials; Cargill, M., Burgess, S., Eds.; University of Adelaide Press: Adelaide, Australia, 2017; pp. 169-186.

111. Shaw, O.; Voss, S. The delicate art of commenting: Exploring different approaches to editing and their implications for the author-editor relationship. In Publishing Research in English as an Additional Language: Practices, Pathways and Potentials; Cargill, M., Burgess, S., Eds.; University of Adelaide Press: Adelaide, Australia, 2017; pp. 71-86.

112. Hyland, K. Academic publishing and the myth of linguistic injustice. J. Second Lang. Writ. 2016, 31, 58-69. [CrossRef]

113. Heng Hartse, J.; Kubota, R. Pluralizing English? Variation in high-stakes academic texts and challenges of copyediting. J. Second Lang. Writ. 2014, 24, 71-82. [CrossRef]

114. Latour, B.; Woolgar, S. Laboratory Life: The Construction of Scientific Facts; Princeton University Press: Princeton, NJ, USA, 1979.

115. Cadman, K. Introducing research rigour in the social sciences: Transcultural strategies for teaching ERPP writing, research design, and resistance to epistemic erasure. In Publishing Research in English as an Additional Language: Practices, Pathways and Potentials; Cargill, M., Burgess, S., Eds.; University of Adelaide Press: Adelaide, Australia, 2017; pp. 33-54.

116. Curry, M.J.; Lillis, T. A Scholar's Guide to Getting Published in English: Critical Choices and Practical Strategies; Multilingual Matters: Bristol, UK, 2013.

117. Badenhorst, C.; Xu, X. Academic Publishing: Making the Implicit Explicit. Publications 2016, 4, 24. [CrossRef]

118. Kuteeva, M.; McGrath, L. Taming Tyrannosaurus rex: English use in the research and publication practices of humanities scholars in Sweden. Multilingua 2014, 33, 365-387. [CrossRef]

119. Martín, P.; León Pérez, I.K. Convincing peers of the value of one's research: A genre analysis of rhetorical promotion in academic texts. Engl. Specif. Purp. 2014, 34, 1-13. [CrossRef]

120. Swales, J. Standardisation and its discontents. In Publishing Research in English as an Additional Language: Practices, Pathways and Potentials; Cargill, M., Burgess, S., Eds.; University of Adelaide Press: Adelaide, Australia, 2017; pp. 239-253.

121. Gu, X.; Blackmore, K.L. Recent trends in academic journal growth. Scientometrics 2016, 108, $693-716$. [CrossRef]

122. Curry, M.J. Graphics as invention heuristics in writing for publication by academic engineers. In Language, Literacy, and Learning in STEM Education: Research Methods and Perspectives from Applied Linguistics; Curry, M.J., Hanauer, D.I., Eds.; John Benjamins: Amsterdam, The Netherlands, 2014; pp. 87-106.

123. Simpson, S. Systems of writing response: A Brazilian student's experiences writing for publication in an environmental sciences doctoral program. Res. Teach. Engl. 2013, 48, 228-249.

124. Li, Y. Mentoring junior scientists for research publication. In Novice Writers and Scholarly Publication: Authors, Mentors, Gatekeepers; Habibie, P., Hyland, K., Eds.; Palgrave Macmillan: Cham, Switzerland, 2019; pp. 233-250.

(C) 2019 by the authors. Licensee MDPI, Basel, Switzerland. This article is an open access article distributed under the terms and conditions of the Creative Commons Attribution (CC BY) license (http://creativecommons.org/licenses/by/4.0/). 